\title{
PREREQUISITES FOR PROMOTING INNOVATION PROJECTS IN THE AGRICULTURAL SECTOR
}

Zenija Kruzmetra1, Dr. geogr. /Assoc. prof.; Kristine Cinglere'2, Mg.proj.mgmt.;

Dina Bite ${ }^{3}$, Dr.sc.soc. /Assoc.prof.

\author{
1, 3 Latvia University of Life Sciences and Technologies, ${ }^{2}$ Latvian Rural Advisory \\ and Training Centre
}

\begin{abstract}
According to the European Innovation Partnership for Agricultural productivity and Sustainability (EIP-AGRI) that started 2012, the Europe 2020 Flagship Initiative "Innovation Union" specifies European Innovation Partnerships (EIP) as a new tool for speeding up innovation through linking existing policies and instruments. Based on the report "Innovation, Agricultural Productivity and Sustainability in Latvia" prepared by the Organization for Economic Co-operation and Development (OECD) in 2019, it analyses innovations in agriculture in order to promote further development of the sector. The agricultural sector has progressed more slowly than the economic sector and slightly more needs to be invested in order to ensure a well-functioning innovation system and a policy environment that would increase agricultural productivity and improve sustainability.

The aim of paper is to reveal what prerequisites are necessary to promote the development of innovation projects in agricultural sector. The research based on analysis of documents exploring the views of European Innovation Partnership project managers on how the innovation process in European Innovation Partnership projects has taken place and what are the main preconditions for promoting the development of innovation projects, as well as observation and semistructured interview, in turn, exploring, which can contribute to the development of innovation projects.

As a result of the research, 8 preconditions for the promoting development of innovation projects in agriculture were identified. The results of the research can have a significant impact on the development of innovation, identifying weaknesses, problems that need more attention and take specific activities to improve the current situation.
\end{abstract}

Key words: innovation projects, projects promoting prerequisites, agriculture.

JEL code: Q1, Q16.

\section{Introduction}

The understanding of the concept of 'innovation' is very diverse. In Latvia, innovation is defined as "the process by which new scientific, technical, social, cultural or other ideas, developments and technologies are implemented in a marketable and competitive product or service." (Kas ir inovacija?, [s.a.]). According to the Organization for Economic Co-operation and Development (OECD), innovation is "a key driver of productivity, sustainable growth and prosperity." (Enhancing rural innovation, 2018). It has been debated for years whether the terms 'innovation' and 'project management' should be used in the same sentence. However, researchers do not agree on this issue either, as opinions are divided. As innovation means the process from idea to realization, in theory and practice, the focus is on what is considered a project. From a theoretical point of view, both innovation management and project management have developed over time as two independent disciplines. On the other hand, practice shows the opposite, namely that the most effective way to manage the life cycle of the innovation process is through project management. Respectively, innovations are mainly developed by applying project management principles. One of the definitions that explains the link between innovation and project management identifies innovation projects as system management to ensure that the project outcome is in line with its objectives (Key Issues to..., 2017). Innovation projects tend to start with freely defined, sometimes even ambiguous goals, which become clearer in the process of project continuation. The processes used are more experimental and exploratory and rarely use strict linear requirements (Project Management vs..., [s.a.]). Innovation projects refer to those projects that aim to innovate in an existing system or practice. Generally speaking, this is

1 zenija.kruzmetra@llu.Iv

2 kristinecinglere@gmail.com

3 dina.bite@llu.Iv 
something new to replace an existing activity (Innovation Projects vs..., [s.a.]). Innovation projects can be divided into incremental and radical. Incremental innovation projects improve an existing product, service or process, while radical innovation projects find completely new, unprecedented ways to create / do something (How many types..., 2016).

There has been an increasing focus on innovation in agriculture and on how change in the agricultural sector can take place (Conceptualising the DAI..., 2019; Coutts, J. et al., 2017; Lambrecht, E. et al., 2014). According to the European Innovation Partnership for Agricultural productivity and Sustainability (EIP-AGRI) that started 2012, the Europe 2020 Flagship Initiative "Innovation Union" specifies European Innovation Partnerships (EIP) as a new tool for speeding up innovation through linking existing policies and instruments. Based on the report "Innovation, Agricultural Productivity and Sustainability in Latvia" prepared by the Organization for Economic Co-operation and Development (OECD) in 2019, it analyzes innovations in agriculture in order to promote further development of the sector (Inovacijas, lauksaimniecibas produktivitate..., 2019). The agricultural sector has progressed more slowly than the economic sector and slightly more needs to be invested in order to ensure a well-functioning innovation system and a policy environment that would increase agricultural productivity and improve sustainability. The main shortcoming identified is the lack of cooperation between research institutions and rural entrepreneurs - practitioners who put research results into practice (Inovacijas, lauksaimniecibas produktivitate..., 2019). The lack of innovation in agriculture has led to the search for new basic principles to improve the situation, for example, the innovation system helps to understand how the agricultural innovation process works, can improve its importance and quality, and weigh what is needed to develop innovation (Agricultural Innovation Systems, [s.a.]; Chesbrough, H. W., Bogers, M., 2014; Hargadon, A., 2014; Rost, K., 2011).

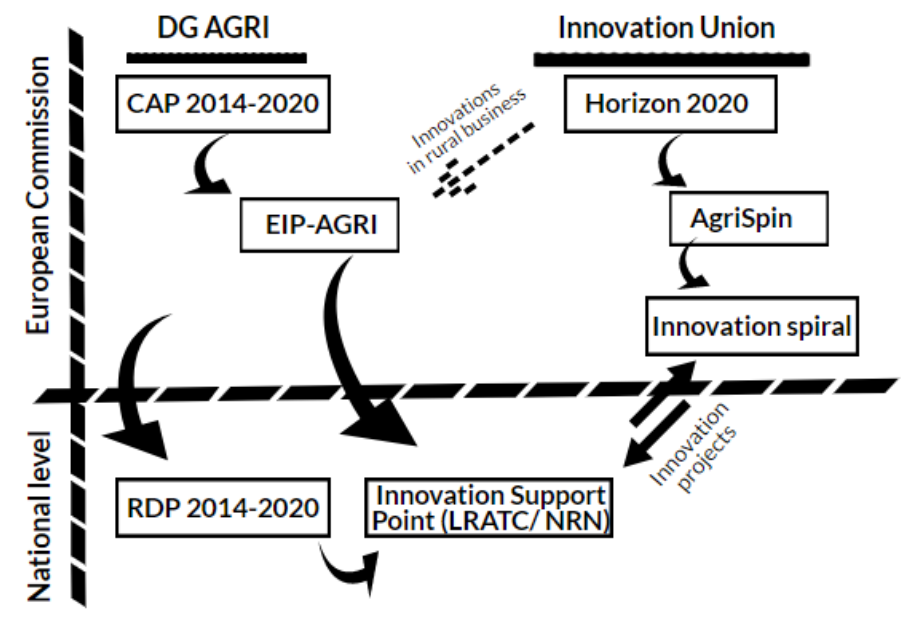

Source: created by authors, based on document analysis

Fig. 1. Political system of agricultural innovation projects

The Innovation Support Point is given a major role in promoting innovation. Innovation Support Points facilitate networking activities by improving communication, knowledge sharing and knowledge exchange in conferences, focus groups, seminars and publications. The main goal is to stimulate communication between all members of the EIP working group (Innovation support services, 2014). A new approach to promoting innovation in agriculture and forestry has been implemented in Europe. Namely, they are innovation brokers. The broker connects innovation actors (farmers, researchers, NGOs etc.) around an idea that can become an innovation. Brokers help to find and develop innovative ideas, find suitable partners and funding, as well as identify potential roles for each partner (Innovation support services, 
2014). The political system of agricultural innovation projects consists of two levels - European and national (Fig. 1). The European Innovation Partnership Network at European Union level is the EIP-AGRI support point in Brussels. At the national level, the Latvian Rural Advisory and Education Centre is a support point or contact point, which in connection with the functions of the National Rural Network provides technical assistance for the development of creative project ideas, establishment of potential EIP working groups and attraction of potential partners (Valsts un Eiropas..., 2017). So far, 67 European Innovation Partnership projects have been launched in Latvia. In comparison with other countries, for example, 244 projects have been launched in the Netherlands and 404 - in Italy (Projects..., [s.a.]).

The aim of paper is to reveal what prerequisites are necessary to promote the development of innovation projects in agricultural sector. In order to achieve the goal of the study, the following tasks were set: 1 . To study the theoretical characteristics of innovation projects and innovation project management; 2 . To study the promotion of innovation projects in the agricultural sector; 3. To carry out research of preconditions for the development of innovation projects.

The research based on analysis of documents exploring the views of European Innovation Partnership project managers on how the innovation process in European Innovation Partnership projects has taken place and what are the main prerequisites for promoting the development of innovation projects, as well as observation and semi-structured interview, in turn, exploring, which can contribute to the development of innovation projects and which is already being done. A total of four interviews were conducted with European Innovation Partnership project managers and five events were observed. The aim of the observed and visited activities was to identify the preconditions that promote and hinder the development of innovation projects in agriculture.

The results of the research can have a significant impact on the development of innovation, identifying weaknesses, problems that need more attention and take specific activities to improve the current situation. Research questions are: 1 . What is the need for innovation projects to be able to improve the current situation in the agricultural sector? 2. What are the most important prerequisites for the development of innovation?

\section{Research results and discussion}

The first part of the study covers the monitoring of measures to promote five innovation projects in agriculture: Administrative issues in European Innovation Partnership operational group projects (2 venue), Nordic-Baltic Rural Network Innovation seminar, Conference "Innovation for Development", Publicity of the final report of the European Innovation Partnership project (Table 1). All events are focused on the challenges and solutions for the development of innovation projects, they took place in the period from March 14, 2019 - March 4, 2020. 
Observed Innovation Venues

\begin{tabular}{|l|c|c|c|c|}
\hline No. & Name of the event & Target audience & Time & Venue \\
\hline $\begin{array}{l}\text { 1., } \\
\text { 2. }\end{array}$ & $\begin{array}{c}\text { Administrative issues in European } \\
\text { Innovation Partnership operational } \\
\text { group projects I, II (2 working } \\
\text { groups organized) }\end{array}$ & $\begin{array}{c}\text { Project managers, } \\
\text { coordinators, RSS, MA, } \\
\text { NRN }\end{array}$ & $\begin{array}{c}14.03 .2019 . \\
15.10 .2019 .\end{array}$ & $\begin{array}{c}\text { LRATC, } \\
\text { Ozolnieki, } \\
\text { Latvia }\end{array}$ \\
\hline 3. & $\begin{array}{c}\text { Nordic-Baltic Rural Network } \\
\text { Innovation seminar }\end{array}$ & $\begin{array}{c}\text { Nordic-Baltic Rural } \\
\text { Network employees, EIP- } \\
\text { AGRI contactpersons }\end{array}$ & 21.01 .2020$. & $\begin{array}{c}\text { Tallinn, } \\
\text { Estonia }\end{array}$ \\
\hline 4. & $\begin{array}{c}\text { Conference "Innovation for } \\
\text { Development" }\end{array}$ & $\begin{array}{c}\text { All those who are } \\
\text { interested in innovation }\end{array}$ & 27.02 .2020$. & $\begin{array}{c}\text { Vidzeme } \\
\text { Concert Hall, } \\
\text { Cesis, Latvia }\end{array}$ \\
\hline 5. & $\begin{array}{c}\text { Publicity of the final report of the } \\
\text { European Innovation Partnership } \\
\text { project }\end{array}$ & $\begin{array}{c}\text { Project team, MA, RSS, } \\
\text { NRN }\end{array}$ & $\mathbf{0 4 . 0 3 . 2 0 2 0 .} \begin{array}{c}\text { Cesvaine dairy } \\
\text { plant, Latvia }\end{array}$ \\
\hline
\end{tabular}

Source: created by authors

The aim of the observed and attended activities was to identify what may promote or hinder the development of innovation projects.

The first event observed was "Administrative issues in European Innovation Partnership operational group projects - I". The aim of this event was to understand and clarify the administrative difficulties faced by EIP project team project managers and what is planned to improve the overall implementation of EIP projects. As a feature of promoting innovation projects - the Rural Support Service is very much thinking about how the implementation of EIP projects can be improved, trying to address how the administrative burden for project managers and project coordinators can be eased. Referring to the fact that this was the first meeting for all - EIP project managers, the Ministry of Agriculture, the Rural Support Point and the National Rural Network, a number of issues faced by innovation participants were highlighted. One of the problems was the publicity of the results. As the project is funded by the European Agricultural Fund for Rural Development, this means that the results cannot be patented and these research projects must be reported. The lack of communication between all parties involved has created unresolved issues. In order to be able to contribute to the development of innovation projects in general, it is necessary to think about what events will be organized, what training will be needed for EIP project managers and what is related to reducing administrative burdens in general.

The second observed venue with the same title was working group about "Administrative issues in European Innovation Partnership operational group projects - II". The aim of this innovation measure was to find out the current issues that have hindered the administration of innovation projects so far. The first problem is that it turns out that EIP project managers did not know or were not aware of the need for regular publicity for these projects. Thus, one of the most important preconditions for the promotion of innovation projects is visible - publicity of projects. The second problem is the public procurement procedure. When administering EIP projects, it was not clear to many what could be considered as eligible costs and what could be considered as ineligible costs. Another problem faced by innovation actors, in this case innovation project managers, is the lack of mutual understanding of what each party - the Rural Support Service, the Ministry of Agriculture and the National Rural Network - wants to expect from project managers. Among other things, the project managers emphasized that a lot of problems are caused by quality implementation of the Minister Cabinet Regulation No. 222., as a number of rules do not seem logical and there is a need to think hard about how to change them. For example, 
LRATC could organize preparatory training with its professional skills. The training would be designed to train potential EIP project managers, farmers, researchers etc. and tell what each institution expects from them, and possibly help prepare a project application. Pre-training courses would provide an opportunity to improve communication.

The third observed event was Nordic-Baltic Rural Network Innovation seminar in Tallinn, Estonia. The aim of the event was to prepare a presentation on the main activities of the innovation support point and how the development of innovation projects is promoted, and each Member State had to present how innovation projects are promoted. The Scottish Innovation Support Centre is working on a communication plan that can solve many problems, as problems often arise when there is uncertainty about how to do the thing correctly. Another characteristic of promoting innovation projects is that the Scottish Innovation Support Centre is working to train innovation brokers. They currently have 28 brokers, and the main thing they emphasized is that the work of an innovation broker requires very different methods from a consultant or researcher and that it is often difficult for those involved to change their work style and methods. In order to be able to solve the problems related to the promotion of innovation, a curriculum has been developed for this activity. As mentioned above, NRN's work plans include training LRATC regional office consultants to become innovation facilitators. However, this work requires resources, additional knowledge, as well as the willingness of the consultants themselves to learn and acquire new knowledge. Scottish Innovation Support brokers organize meetings with farmers (especially in the outermost regions that do not get involved in such projects) to try to identify problems and project ideas. Observing this event, for the most part, innovation participants face a problem such as uncertainty about what constitutes an innovation project, as for some it seemed a simple management practice. As explained above, innovation is a very broad concept and everyone can interpret it in a different way - the key is that the method, the technology etc. does not recur, it must be unique. And it is in this aspect that the responsible institutions have a very important role - to educate the participants of innovation, to tell a wider audience about what is innovation in agriculture or forestry. Participants shared their thoughts that it is not so easy to set up a European Innovation Partnership Task Force, that large resources need to be devoted to this purpose and that this event needs to be developed.

The next observed event is Conference "Innovation for Development". The aim of this event was to present innovations in agriculture, gastronomy, IT etc. A characteristic feature of the promotion of innovation projects is the presence of various stakeholders at the event, as it shows that people are interested in hearing and listening to innovative methods that can develop their business. Specifically, in this event, everyone can be described as participants in innovation. In one of the event's thematic groups, the participant expressed his desire to develop his business, to do things differently, and pointed out that attracting a researcher who could help develop a product requires large financial resources, which he unfortunately does not have. It was in this respect that the responsible institutions, which also attended the event, had to react as to why this participant was not aware of the existence of such financial support for the European Innovation Partnership. Evaluating what needs to be improved in order to promote the development of innovation projects, it can be concluded that the responsible institutions must organize events that would promote people's awareness, education about the essence of the event itself.

The last observed event was Publicity of the final report of the European Innovation Partnership project. The aim of this event was to provide an opportunity for the EIP working group, which has implemented the first innovation project, to present the main results to the Rural Support Service, the Ministry of Agriculture and the National Rural Network. A characteristic feature of promoting an innovation project is the time invested by the EIP project team itself to be able to implement the project. Each project 
participant told how specifically he/she progressed throughout the project, and it is very important to mention that one farmer was very grateful for the opportunity to participate in an innovation project and expressed his readiness to participate in this type of project if given the opportunity. The project team complemented each other during the presentations, which means that everyone has been aware of all the ongoing processes and has been able to express their views. Also, in this event, the EIP working group emphasized that there have been many problems encountered during the implementation of the project, including the qualitative implementation of Cabinet Regulation No. 222. The responsible authorities played an important role in this event, as it was important for the persons in charge to come and hear about the existing problems. In general, it can be concluded that there is enough work to promote the development of innovation projects, but by working together it will be possible to achieve the desired result and the development of innovation projects will be successfully completed.

Observing the events listed above, it can be concluded that innovation projects have attracted many interesting things. European Innovation Partnership projects are a relatively new support opportunity, so there are enough uncertainties about how to properly implement and enforce these projects. The Rural Support Service, together with the State Rural Network, is working to facilitate project implementation for project managers as soon as possible. One of the ways to find answers to the unclear questions is for the National Rural Network to organize seminars, conferences, working groups etc. types of events. It is one of the ways in which more active innovation projects can be promoted.

Through the interviews, the project managers of the European Innovation Partnership were interviewed in order to be able to find out how the innovation process in EIP projects has taken place and what are the main preconditions for the development of innovation projects. The interviewees were selected on the basis of an analysis of documents, which identified which innovation projects in agriculture have been launched in this programming period.

In general, the introduction of innovation projects in the agricultural sector can certainly contribute to the development of the sector. According to the described part of the theory and research, the essence of innovation projects is that it is a great daring to change something that has been traditionally accepted before. And by accepting something new, there is an opportunity to work differently, which can bring unprecedented success.

However, summarizing the results of the research, as well as the opinions of the innovation project managers themselves, the authors conclude that innovation projects have a future for the future growth of the agricultural sector. However, a lot of effort is needed to improve the overall Rural Development Program support measure Nr. 16 "Cooperation". 
Preconditions for the development of innovation projects

\begin{tabular}{|c|c|c|}
\hline No. & Problems / weaknesses & Possible activities \\
\hline 1. & Low interest & $\begin{array}{c}\text { Organization of informative, educational seminars throughout } \\
\text { Latvia }\end{array}$ \\
\hline 2. & Explanation of innovation & Organization of informative, educational seminars \\
\hline 3. & $\begin{array}{l}\text { Innovation-oriented } \\
\text { environment }\end{array}$ & If possible, build a successful project team \\
\hline 4. & Communication & Create a feedback mechanism, develop a communication plan \\
\hline 5. & $\begin{array}{l}\text { Lack of understanding in the } \\
\text { implementation of the project }\end{array}$ & $\begin{array}{l}\text { Organize pre-preparation courses to get acquainted with the } \\
\text { main activities of the project }\end{array}$ \\
\hline 6. & $\begin{array}{l}\text { Administrative burden of } \\
\text { projects }\end{array}$ & $\begin{array}{l}\text { The RSS reduces the administrative burden in project } \\
\text { implementation as much as possible }\end{array}$ \\
\hline 7. & Publicity of projects & NRN has developed a specific action plan \\
\hline 8. & Promoting innovation & Curriculum development for potential innovation brokers \\
\hline
\end{tabular}

\section{Source: created by the authors}

One of the most important preconditions for the development of innovation is the desire of farmers, consultants, researchers and others themselves to accept new challenges and, most importantly, to accept innovation and start thinking about how to cooperate and find solutions for the development of the industry.

The study also revealed the essence of the concept of innovation. For some, this will be a known practice, for some it will be something new and unprecedented, so it is important that the public is informed about what innovation and innovation are in the sector. Because maybe someone is unfamiliar with the innovation and it automatically raises concerns about whether they will be able to implement the innovation project. That is why the role of the NRN is to educate and inform the general public about what innovation is.

An important precondition for being able to foster innovation is its environment. That is, if the innovative idea has no supporters, then the idea will not be advanced at all, although it is very likely that the idea could solve an industry problem. That's why the key is never to lose faith in an idea, and that's why innovation projects need leaders with strong leadership skills.

It is also important to mention that in order for innovation projects to be able to develop, the newly formed project team needs to establish strong communication both with each other and with the employees of the responsible institutions. There is a need for feedback, which is very much needed in these cooperation projects. Therefore, it is already being considered how to help project managers to establish successful communication with both the RSS and farmers etc. In order to be able to move forward, it is necessary to clearly define what each person involved expects in order to be able to resolve all issues as quickly as possible. One of the project managers mentioned that they want to understand what is planned in the project, to find out the understanding of each cooperation partner about their responsibilities and to coordinate the future practical activities of the team. In order for a project to be able to move forward, everyone's contribution to the project and effective communication is important.

In order for the RSS and the Ministry of Agriculture to receive high-quality project applications, one of the suggestions and preconditions was to organize pre-training. The training would be designed to train potential EIP project managers, farmers, researchers etc. They would set out what each institution expects of them and may be able to help prepare a project application. Thus, it would be an opportunity to receive immediate answers on unclear topics. One of the project managers made an important point: "Innovative projects cannot be planned. There is a goal you are striving to achieve. It must be clear and there can be 
no deviation from it." However, the organization of such information and training exercises would provide an opportunity to attract new potential EIP project managers, stakeholders etc., which can lead to innovative ideas. In its turn, the RSS and the Ministry of Agriculture could tell and introduce potential participants in more detail about what is written in the Cabinet Regulation No. 222 and what is expected based on each of the points. As mentioned above, the Cabinet of Ministers regulations No. 222 still cause great misunderstanding and uncertainty about what to do and how to do it right. Because, as already mentioned by the project managers, it has been illogical and administratively difficult to comply with the rules. And so there are misunderstandings that are not pronounced, and in the end all this can lead to mistakes in the implementation of the project.

It follows from the above that project managers are keen to reduce the administrative burden, as farmers refuse to participate in the project due to these strict administrative requirements. Therefore, one of the preconditions for further improvement of the event could be that the RSS could reduce the administrative burden.

Another precondition for the development of innovation is the involvement of existing EIP project managers in the publicity of project results. Publicity is important precisely in order to inspire potential participants in EIP projects to further develop their idea. Publicity should also be given to the benefits of these projects for the development of the sector. And, as one of the project leaders mentioned, it is important that EIP projects are better promoted; this could be the task of the VLT innovation support point, which can be implemented by organizing information seminars, working groups, publishing articles in scientific journals etc.

An important precondition for the further development of innovation is the development of a training program for innovation brokers. An innovation broker would be the most direct facilitator and driver of innovation. As the study found, one of the project managers mentioned that such support in writing the project would have been very useful. At the time of writing, there were a lot of uncertainties about what and how should be done better. As mentioned above, VLT plans to train potential innovation brokers, but there is still a lot of work ahead, as not everyone is able to find an innovative method or technology in traditional practice.

\section{Conclusions, proposals, recommendations}

The interrelationship between innovation and project management identifies new innovation projects that can ensure that the project outcome is in line with its objectives. The theory of the analysis of the stages of the innovation spiral process is as an essential tool for the implementation of innovation projects in practice, because the stages of the innovation spiral can be compared with the traditional project life cycle. Innovation projects in the agricultural sector are needed to diversify and increase the development of the sector, thus facilitating the implementation of innovation projects. As a result of the study, 8 prerequisites for promoting innovation projects in the agricultural sector were identified:

1) The desire of farmers, consultants, researchers etc. to accept new challenges and, most importantly, to accept innovation;

2) Educating and informing the general public about what innovation is and about European Innovation Partnership projects;

3) Promoting the development of innovation requires an innovation-oriented environment as well as leaders with strong leadership skills; 


\footnotetext{
4) The project team must establish strong communication both with each other and with the employees of the responsible institutions;

5) In order to prepare high-quality project applications, one of the preconditions is to organize prepreparation training, introducing potential project managers to the main activities of the project;

6) Reducing the administrative burden of projects;

7) Involvement of European Innovation Partnership project managers in publicizing project results to the general public;
}

8) Training of innovation brokers, as brokers are the most direct promoters of innovation projects.

As a result of the study, several recommendations were developed.

9) In order to promote the development of innovation projects, the authors recommend that the State Rural Network organize an innovation camp. This approach is already widely accepted and used in Europe. Organizing an innovation camp would be an opportunity for all potential European Innovation Partnership project promoters to meet and share their ideas and knowledge.

10) The authors recommend that the National Rural Network develop a communication plan aimed at improving mutual communication between all parties involved - the Rural Support Service, the Ministry of Agriculture, the National Rural Network, as well as with the European Innovation Partnership project managers.

11) In order to be able to develop innovation projects, the Ministry of Agriculture must improve the rules of the support measure, thus including all the above-mentioned aspects, which are necessary to facilitate the implementation and realization of the European Innovation Partnership project.

\section{Bibliography}

1. Agricultural Innovation Systems (s.a.) Retrieved: https://www.g-fras.org/en/good-practice-notes/agriculturalinnovation-systems.html. Access: 10.03.2020.

2. Chesbrough, H. W., Bogers, M. (2014). Explicating Open Innovation: Clarifying an Emerging Paradigm for understanding innovation. In $\mathrm{H}$. Chesbrough, W. Vanhaverbeke, \& J. West (Eds.), New frontiers in open innovation (pp. 3-28). Oxford, UK: Oxford University Press.

3. Conceptualising the DAIS: Implications of the 'Digitalisation of Agricultural Innovation Systems' on technology and policy at multiple levels (s.a.) Retrieved: https://reader.elsevier.com/reader/sd/pii/S1573521418301532?token=6C93B75F80FAB110365D51B2B33CC44 D58CBE8AF3960788E04C574F48822C1F4C858F0A90946CA27D38D4AEA3BBDA5DC. Access: 25.01.2020.

4. Coutts, J., White T., Blackett, P., Rijswijk, K., Bewsell, D., Park, N., Turner, J.A. Botha, N. (2017). Evaluating a space for co-innovation: Practical application of nine principles for co-innovation in five innovation projects. Outlook on Agriculture, Vol. 46(2) 99-107.

5. Enhancing rural innovation (2018). Retrieved: https://www.oecd.org/regional/Proceedings.pdf. Access: 05.01.2020.

6. Hargadon, A. (2014). Brokerage and innovation. In M. Dodgson, D. M. Gann, \& N. Phillips (Eds.), The Oxford handbook of innovation management (p. 163). Oxford, UK: Oxford University Press.

7. How many types of innovation are there? (2016). Retrieved: https://www.innovationexcellence.com/blog/2016/08/16/how-many-types-of-innovation-are-there/. Access: 05.01.2020.

8. Innovation Projects vs. Innovative Projects? What's the difference? (s.a.) Retrieved: https://english.stackexchange.com/questions/205259/innovation-projects-vs-innovative-projects-whats-thedifference. Access: 06.01.2020.

9. Innovation Strategy: An approach in three levels (2015) Retrieved: https://www.kindai.ac.jp/files/rd/researchcenter/management-innovation/kindai-management-review/vol3_10.pdf. Access: 07.01.2020.

10. Inovacijas, lauksaimniecibas produktivitate un ilgtspejiba Latvija (Innovation, Agricultural Productivity and Sustainability in Latvia) (2019.g.) Retrieved: https://www.zm.gov.Iv/public/ck/files/OECD_petijums_LAT.pdf. Access: 09.01.2020.

11. Kas ir inovacija? (What is Innovation?) Retrieved: https://innovation.Iv/inovacija/. Access: 03.01.2020.

12. Key Issues to Improve Innovation Project Excellence (2017.g.) Retrieved:

https://www.intechopen.com/books/key-issues-for-management-of-innovative-projects/key-issues-to-improveinnovation-project-excellence. Access: 10.01.2020. 
13. Lambrecht, E., Kühne, B., Gellynck, X. (2014). How do innovation partners differ with respect to innovation type and stage in the innovation journey of farmers? Entrepreneurship and Innovation, Vol 15, No 3, $2014, \mathrm{pp}$. 191-203.

14. Project Management vs. Managing Innovation Projects (s.a.) Retrieved: https://innovationmanagement.se/imtool-articles/project-management-vs-managing-innovation-projects/. Access: 06.01.2020.

15. Projects (s.a.) Retrieved: https://ec.europa.eu/eip/agriculture/en/findconnect/projects?search_api_views_fulltext_op=OR\&search_api_views_fulltext=\&field_proj_funding_source_list $=0 \&$ field_proj_geographical_area\%5B\%5D=145. Access: 02.02.2021.

16. Rost, K. (2011). The strength of strong ties in the creation of innovation. Research Policy, 40(4), 588-604.

17. Valsts un Eiropas Savienības atbalsta pieskirsanas kartiba 16. pasakuma "Sadarbiba" 16.1. apakspasakumam "Atbalsts Eiropas Inovaciju partneribas lauksaimniecibas ražigumam un ilgtspejai lauksaimniecibas raziguma un ilgtspejas darba grupu projektu istenošanai" un 16.2. apakspasakumam "Atbalsts jaunu produktu, metozu, procesu un tehnologiju izstradei" atklatu projektu iesniegumu konkursu veida (Procedure for granting state and EU Support Measure 16 "Cooperation" for the sub-measure 16.1. "Support to the implementation of the projects of the working groups of the European Innovation Partnership for Agricultural Productivity and Sustainability" and for the sub-measure 16.2. "Support for the development of new products, methods, processes and technologies" in the form of an open project application competition) (2017.g.) LR likums Retrieved: https://likumi.Iv/ta/id/290651-valsts-un-eiropas-savienibas-atbalsta-pieskirsanas-kartiba-16nbsppasakuma-sadarbiba-16-1-apakspasakumam-atbalsts-eiropas. Access: 12.01.2020. 